\title{
Factors that Influence Women Entrepreneurial Success in Malaysia: A Conceptual Framework
}

\author{
Shamsul Hana Abd Rani ${ }^{1}$, Norashidah Hashim² \\ ${ }^{1}$ School of Business Management, College of Business, Universiti Utara Malaysia, Malaysia \\ ${ }^{2}$ School of Business Management, College of Business, Universiti Utara Malaysia, Malaysia
}

\begin{abstract}
A number of factors have been suggested to explain how the success among women entrepreneurs can be improved. To date, some factors have been considered to influence the success of women entrepreneurs such as human capital, networking, financial aids, and opportunity. Despite these studies, entrepreneurial characteristics have been suggested to be studied in order to determine the success among women entrepreneurs. Based on previous literature, there are four characteristics which frequently cited to influence the success among women entrepreneurs which are need for achievement, risk taking, self-confidence and creative and innovative. While for the success of women entrepreneurs, it will be measured by non-financial aspects because women will become less successful if compared in terms of financial aspects since they usually owned small and slower growing business. The contribution of the study are also discussed.
\end{abstract}

Keywords: Women Entrepreneurs, Entrepreneurial Success, Entrepreneurial Characteristics, Risk Taking, Need for Achievement.

\section{INTRODUCTION}

\section{Background of Study}

It has been recognized for a long time that the development of country is also because the contribution of women. Thuaibah, Azlah, Rozeyta, Hishamuddin and Noorizwan (2007) claimed that an increase in the participation of women in labor force indirectly highlighted the increase of women in national development. As mentioned by Hassan and Yusof (2015) the involvement of women in nations' labor force is very important in order to transform the country from developing to developed country. Furthermore, women also have been able to put themselves in the forefront as a leader in many field of expertise such as business, medical, politic, law and etc. (Thuaibah et al., 2007). In addition, the roles of women in business sectors are also recognized worldwide (Ammann, 2013). In fact, Teoh and Chong (2007) stated the involvement of women as entrepreneurs also has been enhanced. Similarly, studies on women entrepreneurs in Malaysia by Alam, Jani and Omar (2011) claimed that women nowadays are not only sticks to the stereotype scenario yet also involved in entrepreneurial landscape which usually dominated by men.

According to the report conducted by the Global Entrepreneurship Monitor (GEM) 2015, the involvement of women in entrepreneurship area are not only contribute for the development of country but also reduce the level of poverty all over the world. In fact, the involvement of women in entrepreneurship is very important in order to mobilize the economic model whereby it creates more opportunities which is more competitive and profitable (Utusan Malaysia, 2010). Pertaining to the Malaysia market place, an economic census done by Department of Statistic in 2011 reported about $19.7 \%$ of women entrepreneurs in Malaysia has been registered with small and medium enterprise (SME). As compared to the year 2005, this percentage is considered increased whereby only $16 \%$ of women entrepreneurs have been registered with SME on that year. Moreover, since January 2013 until June 2014, Ministry of Women, Family and Community Development (2014) revealed about 1645 

in Malaysia: A Conceptual Framework"

women entrepreneurs have been successfully produced through women entrepreneurial program which collaborated with Amanah Ikhtiar Malaysia (AIM). Even though the number of women in entrepreneurship are increased yearly, yet, the numbers of successful women entrepreneurs are still low and not encouraging (Ahmad, Mansor, Ahmad \& Shaikh Ali, 2006; Alam et al., 2011; Yusof \& Karim, 2011).

\section{Problem Statement}

As mentioned by Mitchelmore \& Rowley (2013) the contribution of women entrepreneurs towards economic development is widely known and discussed in previous studies. It is supported by Mattis (2004) and Rehman and Roomi (2012) which proved that the numbers of women entrepreneurs has been increased yearly. However, despite the increase involvement of women in entrepreneurship, the number of women entrepreneurs who succeed are still not encouraging (Alam et. al 2011). For example Kallerberg, Gottschalk and Niefert (2013) claimed that women entrepreneurs are still experienced low business growth and not successful enough.

Similarly, Ahmad et al., (2006) claimed that the number of successful women entrepreneurs in Malaysia also can be considered as low. This is also supported by the previous research which claimed that there is still lack of successful women entrepreneurs in Malaysia (Roddin, Ibrahim, Isa, Warman, Yusof and Karim, 2011). Besides, Akhalwaya and Havenga (2012) stated that there is still lack of research done on women entrepreneurial success even though the entrepreneurial studies are continually conducted. Moreover, Azmin et al. (2011) and Teoh and Chong (2007) also claimed that only a few of research has been conducted to find the reason of successful women entrepreneur in Malaysia.

Owens (2003) in his studies claimed that there are still uncertainties of characteristics which lead to the success of women entrepreneurs. Therefore, in order to fill in this gap, this study is going to find the entrepreneurial characteristics that may affect the women entrepreneurial success. In addition, Shamsul Huda (2014) had also suggested to study the entrepreneurial characteristics by multidimensional for future research. Thus, there is a need to study on the entrepreneurial characteristics such as need for achievement, risk taking, self-confidence and creative and innovative because these characteristics were mostly cited compared to others based on previous studies (Ehigie \& Umoren, 2003; Ummah \& Gunapalan ,2012; Fatimah Hassan et al. ,2014; Hoe et al. ,2012; Lai et al. ,2010; Mendryk \& Dylon ,2014). To add, Teoh and Chong (2007) stressed that Malaysian women entrepreneur need to understand the characteristics needed in order to succeed in their ventures.

\section{Research Objective}

1. To examine the relationship between entrepreneurial characteristics and women entrepreneurial success.

1a. To examine the relationship between need for achievement and women entrepreneurial success

1b. To examine the relationship between risk taking and women entrepreneurial success

1c. To examine the relationship between self-confidence and women entrepreneurial success

1d. To examine the relationship between creative and innovative and women entrepreneurial success.

\section{Contribution of Study}

The study is important in terms of identifying the factors that lead to the success among women entrepreneurs. In addition, it also need to be recognized the factors that contribute to success among women because it will help them to access more business opportunities which then leads them to grow 
Shamsul Hana Abd Rani \& Norashidah Hashim "Factors that Influence Women Entrepreneurial Success in Malaysia: A Conceptual Framework"

their business (Teoh \& Chong, 2007). Furthermore, Teoh and Chong (2007) added by understanding the factors that influence the success of women entrepreneurs, Malaysian women entrepreneurs will be able to broaden their business globally. In line with that, this study is going to determine the factors which contribute and lead women to be a successful entrepreneurs. Meanwhile, from theoretical perspective, this study may help to add to the women entrepreneurs' literature by extending the body of knowledge on factors of women entrepreneurial success. In fact, the findings will provide a better understanding to women entrepreneurs on how to become a successful in their business. In addition, this study provide an alternative in describing entrepreneurial success among women by measuring the success subjectively in terms of entrepreneurial satisfaction and satisfaction in balancing between work and family instead of other measurement such as income, growth etc.

\section{LITERATURE REVIEW AND HYPHOTHESIS DEVELOPMENT}

\section{Women Entrepreneurial Success}

Based on previous literature, entrepreneurial success also discussed in several terms such as venture performance, business success, entrepreneur performance, venture survival and venture growth (Teoh \& Chong, 2007; Shane \& Nicolaou, 2013; Gottschalk, Greene, Hower, \& Muller, 2014). As mentioned by Alam et al. (2010), women entrepreneur would not view as successful if their success is measured by economic perspectives because the business that owned by women frequently small in size and slower growth. Fenwick and Huttons (2000) supported in their study that many women has described success subjectively such as the freedom to choose daily activity, ability to balance between work and family, contribution to the community, reputation, children and the quality of life that they achieve. Most of women entrepreneurs as well recognized the success if and only they able to achieve a balance between the roles in business and family due to the multiple roles and the difficulties in handling both roles at the same time (Fenwick \& Huttons, 2000). As an example, Osrer and Riding (2004) has been interpreted the success among women entrepreneurs through balance between work and life, religious attachment and sustain personal and customer relationship.

Several research on entrepreneurial success among women has been conducted in previous studies (Lai et.al. 2010; Azmin et al., 2011; Alam et al., 2011 ; Ummah and Gunapalan, 2012; Rao et al., 2013; Ranasinghe,2012; Ehigie \& Umoren, 2003; Ekpe, 2011; Chitra, 2014; Prasad, Naidu, Murthy, Winkel \& Ehrhardt, 2013). However, Teoh and Chong (2007) claimed that research that focusing on women entrepreneurs success in Malaysia are still insufficient (Teoh and Chong, 2007). Therefore this study aims at filling this gap. Several factors have been identified that contribute to the entrepreneurial success among women. One of the important factors to highlight among success women entrepreneurs are psychological characteristics and several studies also have been conducted to see the influence of this variable towards the success of women entrepreneurs (Lai et al., 2010; Hoe et al., 2012; Ummah and Gunapalan, 2012; Ranasinghe, 2008; Chitra, 2014; Katongole et al., 2013; Fuad and Bohari, 2011). In addition, Fuad and Bohari (2011) stressed that study on psychological characteristics is very important because it can determine the success among women entrepreneurs.

\section{Entrepreneurial Characteristic and Women Entrepreneurial Success}

Nurwahida and Abdul Manaf (2012) claimed that entrepreneurial characteristics are very important to be identified among entrepreneurs as it has receive attention all over the world. More studies have been conducted on entrepreneurial characteristics which relate with the success of entrepreneurs (Rauch \& Freese, 2000). In fact the studies of entrepreneurial characteristics among women entrepreneurs has also been conducted since decades ago. As mentioned by Olakitan and Ayobami (2011) in order to judge whether entrepreneurs will carried out their business successfully a deeper 

in Malaysia: A Conceptual Framework"

understanding of the entrepreneurs personality need to be studied. As mentioned by Olakitan and Ayobami (2011) even though many factors may lead to the success, however the entrepreneurs is the greatest determinant of their own success. Therefore, many studies have been conducted on the entrepreneurial characteristics due to its importance (Mendryk \& Dylon, 2014). Moreover, Fuad and Bohari (2011) added research on these characteristics is very important because it helps to determine the characteristics that possess by women entrepreneurs to achieve their success. In addition, Jain and Ali (2011) claimed that in order to develop more chances to be a successful entrepreneurs, the characteristics are very important to be recognized and sharpened. It is supported by Omar et al. (2015) that entrepreneurs need to have strong characteristics to become a successful in future.

H1: There is a relationship between entrepreneurial characteristics and women entrepreneurial success.

\section{Need for Achievement and Women Entrepreneurial Success}

A person with need for achievement refer to the one who prefer a moderate difficulty task, accept responsibility and look for the outcomes (Rauch \& Frese, 2007). Nurwahida (2007) claimed that most of successful women entrepreneurs have the characteristics of need for achievement compared to other characteristics. Besides, among risk taking and locus of control, need for achievement is also one of the important characteristics as mentioned by Rasheed (2001). Furthermore, a higher level of need for achievement can be found in business founders besides its very important for the development of economic and business growth (Rasheed, 2001). It is supported by White et al. (2008) who mentioned that the achievement behaviour is not only encourage the entrepreneurs to become succeed but it also avoid to be a failure.

\section{H1a: There is a relationship between need for achievement and women entrepreneurial success}

\section{Risk Taking and Women Entrepreneurial Success}

Besides need for achievement, risk taking is also identified as one of the dimension in entrepreneurial characteristics that influence the success among women entrepreneurs. As mentioned by Hassan et al., (2014), it is described as the willingness of entrepreneurs to involve in the risky work. In another study conducted by Nurwahida (2007), risk taking is referred as entrepreneur's orientation towards taking chances in making an uncertain decision. While Chee (2007) has refer the success of women is whenever the women is willing to take challenge in uncertain decision. It is supported by Ranasinghe (2008) who claimed that risk taking has been found as one of the characteristics which lead to the success among women entrepreneurs.

\section{$\boldsymbol{H 1 b}$ : There is a relationship between risk taking and women entrepreneurial success}

\section{Self-Confidence and Women Entrepreneurial Success}

According to Aycan (2004) women with self-confident are the women who do not easily give up and also do not have many excuses such as husband and children in achieving their goals. Besides, Nurwahida (2007) claimed that in order to success entrepreneurs in general should believe that they able to achieve what has been set for their goals and they should have a confidence in themselves. Furthermore, Koh (1996) mentioned entrepreneurs need to be competent with their business and also have high self-esteem. It is supported by Rieger (2012) who highlighted one of the personal characteristics need by entrepreneurs to achieving their success is self-confidence. In addition, Hassan et al (2014) in their study among rural women entrepreneurs in Malaysia has defined confidence as the belief of the entrepreneurs towards their business that has been established and also their willingness to face any challenge or unexpected failure in future. In fact, Hassan et al. (2014) has 
Shamsul Hana Abd Rani \& Norashidah Hashim "Factors that Influence Women Entrepreneurial Success in Malaysia: A Conceptual Framework"

claimed that self-confidence is the critical contributor for the success of women entrepreneurs. Besides, entrepreneurs with self-confidence in running their business able to go through obstacles, have higher aim and develop better strategy for their business (Moloi \& Rapita, 2014).

\section{H1c: There is a relationship between self-confidence and women entrepreneurial success}

\section{Creative and Innovative and Women Entrepreneurial Success}

Innovativeness has been claimed as a core characteristics of entrepreneur (Rauch \& Freese, 2000; Rieger, 2012). In another study by Schumpeter (1939), entrepreneurs has been characterized as innovative as result from their creativity and knowledge (LeBlanc, 2013). Peprah (2012) has stressed the important of entrepreneurs to be innovative since the absence of the characteristics might lead to low survival rate among women entrepreneurs. Hassan et al. (2014) interpret creative and innovative as entrepreneur's ability in introducing and bringing out new ideas for their business. As been mentioned earlier, women entrepreneurs facing a lot of barriers in the path of growing their business. However, according to Bakri and Mardziyah (2012) women entrepreneurs usually are more creative in solving their problems for the success and growth of their business. Besides, women also are said to be more innovative in promoting their products as well as their services. Innovation is proven as one of the critical factor to succeed but other characteristics also should not be neglected in order to examine their effect towards business that run by female entrepreneurs (Lai et al., 2010).

H1d: There is a relationship between creative and innovative and women entrepreneurial success.

\section{CONCEPTUAL FRAMEWORK}

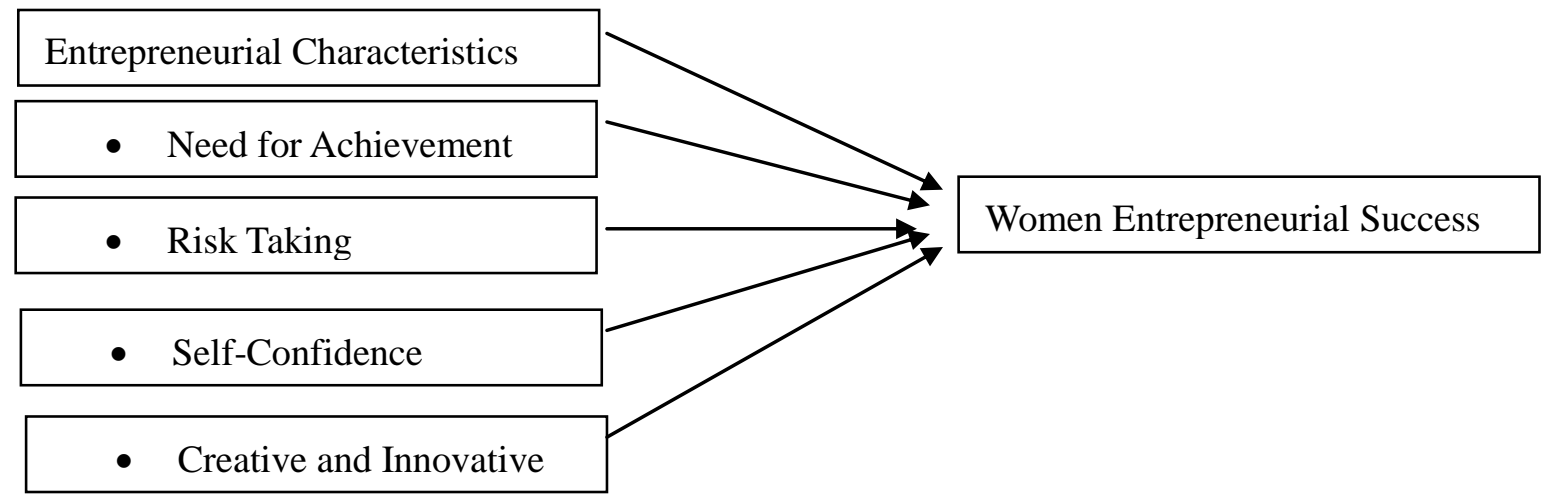

\section{CONCLUSION}

The involvement of women in nations labor force nowadays, is very important for the economic and national development and also to transform the country from being developing to developed country. In addition, the involvement of women is so important to mobilize the economic model that indirectly creating more opportunities for them through involvement in entrepreneurship which is more competitive and profitable. In another words, the development of the country will be remained stagnant without involvement from women in entrepreneurship field. Even though the numbers of women entrepreneurs are increasing yearly, however, women entrepreneurs are still lag behind and not successful compared to men due to several reasons.

Therefore, factors that contribute to success among women need to be recognized as it will help them to be effectively in accessing business opportunity which then leads them to grow their business. By understanding the factors that influence the success or performance among women entrepreneurs, Malaysian women entrepreneurs will be able to broaden their business successfully in globalized environment. Thus, the main objective of this study is to examine the relationship between individual factors (entrepreneurial characteristics, work experience and training) with women entrepreneurial success. 
Shamsul Hana Abd Rani \& Norashidah Hashim "Factors that Influence Women Entrepreneurial Success in Malaysia: A Conceptual Framework"

\section{ACKNOWLEDGEMENT}

The first author would like to thank Dr. Norashidah for her guidance, supervision and assistance in this study.

\section{REFERENCES}

[1] Ahmad, N., Mansor, N., Ahmad, Z. \& Ali, S.H.S. (2006). Faktor-faktor Memotivasikan Wanita untuk Menjadi Usahawan: Satu Kajian Terhadap Usahawan Wanita di Dungun. Retrieved from http://ir.uitm.edu.my/ 5596/1/LP_NORSIDAH\% 20AHMAD\%2006_24.pdf

[2] Akhalwaya, A., \& Havenga, W. (2012). The barriers that hinder the success of women entrepreneurs in Gauteng, South Africa. OIDA International Journal of Sustainable Development, 3(5), 11-28.

[3] Alam, S., Jani, M. \& Omar, N. (2011). An empirical study of success factors of women entrepreneurs in Southern region in Malaysia. International Journal of Economics and Finance, 3(2), 166-175.

[4] Ammann, P. (2013). What Will It Take for Women to Get Ahead in Leadership?

[5] Aycan, Z. (2004). Key success factors for women in management in Turkey. Applied Psychology: An International Review, 53(3), 453-477. http://doi.org/10.1111/j.14640597.2004.00180.x

[6] Azmin, N., Nordin, M., \& Woon, C. C. (2011). Factors Affecting Profitability Of Women Entrepreneurs Business In Malaysia, (Asbes), 972-985.

[7] Bakri, M., \& Mardziyah, A. (2012). Developing sustainable growth model for women entrepreneur in Malaysia: case study in Johor Bahru (Doctoral dissertation, Universiti Teknologi Malaysia, Faculty of Management and Human Resource Development).

[8] Chitra, M. (2014). Influence of personal factors on women entrepreneurs for success in beauty salon industry, 15(1), 76-84.

[9] Ehigie, \& Umoren. (2003). Psychological Factors Influencing Perceived Entrepreneurial Success Among Nigerian Women in Small-Scale Businesses, 5(1), 78-95

[10] Ekpe,I ., Mat., N., Razak, R. C. (2010). The effects of microfinance factors on women entrepreneurs in Nigeria: A conceptual framework. International Journal of Business and Social Science, 1(2), 255-263.

[11] Fatimah, H., Aznarahayu, R., \& Nasina, M. D. (2014). Rural women entrepreneurs in Malaysia: What drives their success? International Journal of Business and Management, 9(4), 10-21. http://doi.org/10.5539/ijbm.v9n4p1

[12] Fenwick, T. J., \& Hutton, S. (2000), "Women crafting new work: The learning of women entrepreneurs" available at http://hdl.voced.edu.au/10707/80551

[13] Global Entrepreneurship Monitor. (2015). Global Entrepreneurship Monitor Special Report: Women Entrepreneurs.

[14] Gottschalk, Greene, Hower, \& Muller. (2014). If you don't succeed, should you try again? The role of entrepreneurial experience in venture survival.

[15] Hamed, A. B., \& Deraman, N. (2002). Jaringan usahawan: Satu pengenalan.Jelapang, 3(1), 9194.

[16] Hassan, K. \& Yusof, R. (2015). Women in Economic and Social Transformation Era: Issue and Challenges.UUM Press.

[17] Hoe, C. H., Isa, F., Hin, C. W., Yunus, J. M., \& Abdullah, H. H. (2012). Development of Women Entrepreneurs : The Case of Malaysia. World Journal of Social Sciences, 2(6), 123-145.

[18] Jain, R., \& Ali, S. W. (2013). Personal Characteristics of Indian Entrepreneurs and Intrapreneurs: An Empirical Study. Management and Labour Studies, 37, 295-322. http://doi.org/10.1177/ 0258042X13484870

[19] Kallerberg, A. \& Leicht, K. (2014). Gender and organizational performance: Determination of small busness survival and success. Academy of Management Journal, 34(1), 134-161. 
Shamsul Hana Abd Rani \& Norashidah Hashim "Factors that Influence Women Entrepreneurial Success in Malaysia: A Conceptual Framework"

[20] Koh, H. C. (1996). Testing hypotheses of entrepreneurial characteristics: A study of Hong Kong MBA students. Journal of Managerial Psychology, 11(3), 12-25. http://doi.org/10.1108/ 02683949610113566

[21] Lee Siew Kim, J., \& Seow Ling, C. (2001). Work-family conflict of women entrepreneurs in Singapore. Women in Management review, 16(5), 204-221.

[22] Lai, K., Nathan, R., Tan, K., \& Chan, B. (2010). Effect of Innovation to the Success of Female Entrepreneurs. Journal of Innovation Management in Small and Medium Enterprise, 2010, 1-14. http://doi.org/10.5171/2010.369877

[23] LeBlanc. (2013). The Effect Of Education And Knowledge , Experience , Mentoring , And Risk On The Successful Entrepreneur : A Qualitative Study .PHD Thesis. Capella University.

[24] Lee, M., \& Rogoff, E. G. (2012). Journal of Small Business \& Entrepreneurship Do women entrepreneurs require special training? An empirical comparison of men and women entrepreneurs in the United States, (July 2015). http://doi.org/10.1080/08276331.1998.10593277

[25] Mattis, M. C. (2004). Women entrepreneurs: out from under the glass ceiling. Women in Management Review, 19, 154-163. http://doi.org/10.1108/09649420410529861

[26] Mendryk, I., \& Dylon, D. (2014). Factors of Professional Success for Self-Employed Women. In Human Capital without Borders: Knowledge and Learning for Quality of Life; Proceedings of the Management, Knowledge and Learning International Conference 2014 (pp. 933-938).

[27] Mitchelmore, S. \& Rowley, J. (2013),"Entrepreneurial competencies of women entrepreneurs pursuing business growth", Journal of Small Business and Enterprise Development, Vol. 20 Iss 1 pp. 125-142 http://dx.doi.org/10.1108/14626001311298448

[28] Moloi, K., \& Rapita, M. (2014). The Impact of Fashion Entrepreneurs' Traits on the Success of Fashion Businesses in the Gauteng Province In South Africa. Mediterranean Journal of Social Sciences, 5(4), 78-86. http://doi.org/10.5901/mjss.2014.v5n4p78

[29] Nieman, G. (2001). Training entrepreneurs and small business enterprises in South Africa: a situational analysis. Education + Training, 43(NOVEMBER 2001), 445-450. http://doi.org/ 10.1108/00400910110411639

[30] Nurwahida Fuad \& Bohari, A. M. (2011). Malay Women Entrepreneurs in the Small and Medium Sized ICT-Related Business : A Study on Need for Achievement, 2(13), 272-278.

[31] Olakitan, O \& Ayobami, A.(2011). An investigation of personality on Entrepreneurial success. Journal of Emerging Trends in economic and management sciences, 2(2) , 95-103.

[32] Owens, K. S. (2003). An Investigation of Personality Correlates of Small Business Success.

[33] Prasad, V. K., Naidu, G. M., Murthy, B., Winkel, E., \& Ehrhardt, K. (2013). Women entrepreneurs and business venture growth: an examination of the influence of human and social capital resources in an Indian context. Journal of Small Business \& Entrepreneurship, 26(4), 341-364. http://doi.org/10.1080/08276331.2013.821758

[34] Ranasinghe, S. (2012). Factors contributing to the success of women entrepreneurs in Sri Lanka. Sri Lanka Journal of Advanced Social Studies, 1(2), 86-110.

[35] Rao, V., Joshi, H. G., \& Venkatachalm, A. (2013). A study on entrepreneurial characteristics and success of women entrepreneurs operating fashion and apparel business, 2(2).

[36] Rauch, A., \& Frese, M. (2000). Psychological approaches to entrepreneurial success : A general model and an overview of findings.

[37] Rehman, S., \& Roomi, M. A. (2012). Gender and work-life balance: a phenomenological study of women entrepreneurs in Pakistan. Journal of Small Business and Enterprise Development, 19(2), 209-228. http://doi.org/10.1108/14626001211223865.

[38] Reynolds, P., Bygrave, W., \& Autio, E. (2004). GEM 2004 Summary Report.

[39] Rieger, K. (2012). Phenomenological exploration of characteristics of successful women entrepreneurs.

[40] Roomi, M. A. \& Parrot, G. (2008). Barriers to development and progress of women entrepreneurs in Pakistan.

[41] Schumpeter, J. A. (Ed.). 1934. The theory of economic development. Cambridge, Mass: Harvard University Press. 
[42] Shamul Huda (2014). The antecedents and impacts of entrepreneurial quality on entrepreneurial success in graduate entrepreneur context. PHD Thesis. University Kebangsaan Malaysia.

[43] Shane, S., \& Nicolaou, N. (2013). The genetics of entrepreneurial performance. International Small Business Journal, 31(5), 473-495. http://doi.org/10.1177/0266242613485767

[44] Teoh, W.M.Y \& Chong, S. C. (2007). Theorising a framework of factors influencing performance of women entrepreneurs in Malaysia. Journal of Asia Entrepreneurship and Sustainability, 3(2), 1-17.

[45] Thuaibah@Suaibah, A. B., Azlah, M. A., Rozeyta, O., Hishamuddin, M. S., \& Syaharizatul Noorizwan, M. (2007). Penglibatan Kaum Wanita Dalam Aktiviti Keusahawanan Di Negeri Johor: Kajian Terhadap Faktor-Faktor Kritikal Kejayaan ( Women' S Involvement in Enterpreneurship in Johor: a Study About Critical Factors in Achievement and Failure in Handling Business ) P. Tesis, 183.

[46] Ummah, \& Gunapalan. (2012). 2012 Factors Influencing on Entrepreneurial Success : an Empirical Study on Women Headed Families in Ampara and Batticaloa Districts in Sri, 1, 141148

[47] Urban, B., Van Vuuren, J. J., \& Barreira, J. D. (2008). High-growth entrepreneurs: the relevance of business knowledge and work experience on venture success.

[48] Utusan Malaysia (2015, February 27). Kuok Kekal Terkaya di Malaysia. Retrieved 12 May 2015 from http://www.utusan.com.my/bisnes/korporat/kuok-kekal-terkaya-di-malaysia-1.64221

[49] Xavier, S. R., Kelley, D., Kew, J., Herrington, M., \& Vorderwülbecke, A. (2013). Global Entrepreneurship Monitor (GEM) 2012 Global Report.GERA/GEM.

\section{AUTHORS' BIOGRAPHY}

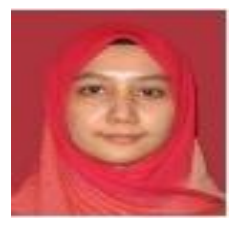

Shamsul Hana Abd Rani, is a PHD scholar at School of Business Management, College of Business from Universiti Utara Malaysia, Malaysia.

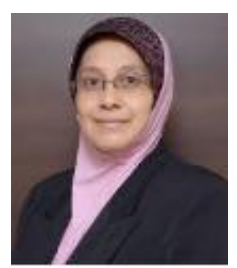

Dr. Norashidah Hashim, is a senior lecturer at School of Business Management, Universiti Utara Malaysia. She is currently serves as Deputy Director for Training and Consultation Department, Co-operative and Entrepreneurship Development Institute (CEDI). 